\title{
Capital Punishment and the Scottish Criminal Justice System
}

Capital punishment has a long and storied global history. However, the eighteenth and nineteenth centuries have received particularly rich and varied analyses as historians of Western Europe have explored how this period was one of discussion, debate and transition in how the death sentence was legislated for and carried out. Despite studies of capital punishment advancing our understanding of eighteenth- and nineteenthcentury penal practices as well as having the potential to offer a unique perspective of the period's social and cultural history, examinations of Scotland's capital punishment history have remained limited. There have been acknowledgements of the country's lesser recourse to the death sentence, especially when compared to England, which perhaps also goes some way towards explaining this relative dearth in historical attention. ${ }^{1}$ In addition, the lack of research into Scotland's criminal history has also been attributed to the difficulties in readily comparing its legal and court systems to practices in England. ${ }^{2}$

Chapter 3 will provide an in-depth exploration of three key periods in Scotland's use of the death sentence and will examine the importance of factors such as geography, unrest and public discourse in shaping judicial opinion and the punishment of certain crimes at certain times. However, this chapter will first examine the nuances of the Scottish legal system that impacted upon the use of the death sentence, and provide a crucial study of how geographical location and population growth and distribution impacted upon the long-term trends in Scotland's use of capital punishment between 1740 and 1834. Furthermore, it will explore the

(C) The Author(s) 2018

R.E. Bennett, Capital Punishment and the Criminal Corpse in Scotland, 1740-1834, Palgrave Historical Studies in the Criminal Corpse and its Afterlife, https://doi.org/10.1007/978-3-319-62018-3_2 
continuities and developments in the use of the death sentence for both murder and property offences over the century to contextualise the peak periods of execution to be discussed in Chap. 3.

\section{The Death Sentence in Scots Law}

Following the Union of 1707 Scotland maintained its own distinct legal system and a large degree of autonomy in its application of the criminal law, a fact acknowledged by historians but, thus far, not extensively explored in relation to the country's use of the death sentence. ${ }^{3}$ A key theme running throughout the current study is that an examination of the Scottish experience of capital punishment can offer a unique, and previously unexplored, perspective of Britain's penal history in this period. Within this, a crucial distinction between England and Scotland was their adoption of capital statutes. The legislation that made up the infamous 'Bloody Code' has been an area of debate for English crime historians. Radzinowicz provided a pioneering and extensive study of the English criminal law in this period, including the legislation passed. However, subsequent historians have challenged his argument that the capital statutes that made up the 'Bloody Code' were created by a disinterested Parliament. ${ }^{4}$ The authors of Albion's Fatal Tree, particularly Hay, focused upon the statutes related to property offences to argue that the authorities used the increased capital statutes as a means of controlling the population. Hay argued that the "decisions that moved the levers of fear and mercy were decisions of propertied men" from the initial prosecution stage to the decision on who to pardon and who to execute. ${ }^{5}$ In his critique of Hay, Langbein instead inferred that the 'Bloody Code' had been passed almost by accident as the statutes lacked proper definition and thus Parliament added "particularity in order to compensate for generality." More recently, King demonstrated that "the whole criminal justice system was shot through with discretion" and examined how the discretionary powers of the legal system were used by a much wider range of people than was argued by Hay, particularly the middle classes. ${ }^{7}$

During the eighteenth and early nineteenth centuries, Scottish writers produced a body of legal literature expounding the distinction of Scots law. ${ }^{8}$ A reading of these commentaries serves to further highlight areas for comparison between the English and the Scottish legal systems and offers some explanations for Scotland's lesser use of capital 
punishment, especially when compared to its southern counterpart. In 1681 Viscount Stair stated that "we are happy in so few and clear statutes." Sir Archibald Alison argued that in England the powers of common law did not generally extend beyond a misdemeanour and that all serious offences were subject to legislative statutes. In consequence, he suggested, the capital statutes were characterised by severity and the judges had limited power to modify the penalties. Comparatively, in Scotland the powers of the common law were more extensive and thus there was less need for the adoption of several of the capital statutes created in the eighteenth century. Evidence of this lay in the fact that there were over 200 defined capital crimes in England when Alison was writing in the early nineteenth century but less than 50 in Scotland, and more than half of these had their origins with the British Parliament. ${ }^{10}$

The lack of a Scottish 'Bloody Code' is important to our understanding of Anglo-Scottish relations in the wake of 1707. The longterm importance of the common law as opposed to statute law and the Westminster Parliament's lack of determination to greatly impose upon Scottish legal autonomy, except at times of unrest notably in the post1745 period, go some way towards explaining the country's lesser use of the death sentence. However, there were also crucial nuances in the Scottish court system that impacted upon their use of capital punishment, one example being the nature of the collection of evidence in potentially capital cases. In Scotland, since the sixteenth century the responsibility for prosecuting offenders was vested in the legal profession, from the Lord Advocate in Edinburgh to the procurator fiscals who would gather evidence, or precognitions, in their local areas and build up the case. In more serious cases the fiscals would send the precognitions to the Crown Office where the Lord Advocate, or in most cases one of his deputes, would decide whether to prosecute in the High Court or its circuit courts. ${ }^{11}$ This system of public prosecution was perhaps more comparable to other Continental European practices than elements of the English system with its heavy reliance upon private prosecution. ${ }^{12}$ Hume argued that Scottish practice was better suited for "repressing the growth of crime" than the English practice where, he stated, the burden of prosecution and conviction lay with the offended party. ${ }^{13}$

Due to the nature of the building up of evidence, Kilday proposed that Scottish criminal trials were only permitted to proceed when the authorities were confident that the case against the accused was "effectively incontrovertible." 14 The process of indicting an accused person also 
garnered favourable comment in the courts. An Advocate Depute stated to the High Court in 1817 that a Scottish indictment "requires more precision, more accuracy and more minuteness than ever was required in any English indictment." 15 In addition, Hume stated that in England no prisoner, except in more modern treason trials, saw their indictment until they stood arraigned for trial. They also remained ignorant of the witnesses to be called against them. However, in Scotland the accused would be given this information at least 15 days before their trial commenced and even the poorest would be afforded defence counsel. ${ }^{16}$ This was a key factor that allowed for defence counsels to argue successfully for a restriction of the charge prior to the commencement of a potentially capital trial and to offer any mitigation for the crime.

Davies argued that if someone was charged with a serious offence before the Court of Justiciary "their chances of survival were slim."17 However, it is the argument here that, due to the nature of the building up of evidence, a relatively high proportion of people brought before the courts received some form of punishment, but not necessarily a death sentence, even for potentially capital crimes. This can largely be attributed to two main reasons. First, in Scotland offenders charged with potentially capital crimes could petition the court before the jury was sworn in. The court would hear the charges against them and the defence counsel would submit the petition for the consideration of the Advocate Depute, who would be acting as the prosecution. If the Advocate Depute consented to the petition, it was usually on the condition that the accused be either banished from Scotland or transported, thus evading the death penalty. This process had the greatest impact on cases where people had been charged with certain property offences, notably housebreaking and theft, and on cases where women had been charged with infanticide. Juries were sometimes reluctant to convict the accused in these kinds of cases, especially if it would result in a death sentence. Significantly, this process allowed for the use of judicial discretion whilst also guaranteeing that a punishment would be meted out.

Second, the court had the power to restrict the level of punishment to be meted out immediately prior to the start of the trial. This process requires some brief explanation. The accused person, who was referred to as the panel in the Scottish courts, would be brought into the court to hear the charges against them. At this point the Advocate Depute and the defence counsel would have the opportunity to debate these charges, in the Scottish court records this would be referred to as 
their debating the relevancy of the libel. In cases that potentially carried a capital punishment the judges could decide to restrict the charges, or the libel, to what was termed an 'arbitrary punishment'. In effect this meant that if the person was found guilty after their trial they could be sentenced to anything short of the death sentence from a fine, corporal punishment, imprisonment, banishment or transportation. If the libel was not restricted to an 'arbitrary punishment' it would be found relevant to 'infer the pains of law', which could be any punishment including the death sentence. The jury would then be sworn in and the trial would begin. ${ }^{18}$ There were also pre-trial processes in England as, at the start of the assizes, the Grand Jury would meet to hear the prosecutor verbally state the evidence to be presented against the accused. The Jury would then decide whether to find a 'true bill' which would send the accused to trial or to find a 'no true bill' or an 'ignoramus' verdict which would often see them discharged. ${ }^{19}$ However, a key difference is that in Scotland the court's decision upon whether there were charges to be answered by the accused also potentially impacted upon the level of punishment the panel would face if convicted. The libel would be restricted predominantly for certain property offences and thus it is important to understand this process when discussing the fluctuations in Scotland's use of capital punishment.

\section{Long-Term Trends in Scottish Capital Punishment}

In Scotland between 1740 and 1834, 797 people were sentenced to death. A total of 505 offenders were executed and 292 were subsequently pardoned, usually on condition of transportation, imprisonment or banishment. ${ }^{20}$ The relatively low number of executions in this period, when compared to England, goes some way towards explaining the limited historiography focused upon the use of capital punishment in Scotland, especially when compared to the vast field focused upon the subject south of the border. However, this study will demonstrate that these figures are by no means insignificant. Instead, they are statistically manageable and thus allow for an in-depth and systematic analysis of the malefactors who met their fate on the scaffolds of Scotland. In addition, this study demonstrates that the Scottish courts, while perhaps more discretionary in their use of the death sentence, were not averse to using the full weight of the law. A quantitative analysis of the criminals sent to the gallows by location and type of offence reveals long-term patterns 
in Scotland's use of capital punishment between the mid-eighteenth and early nineteenth centuries. In addition, a qualitative study of the legal and public responses to criminality across this period bolsters these findings as it demonstrates not only how attitudes towards the use of the gallows were shaped but also how they impacted upon the sheer number of offenders who met their fate at the end of the hangman's rope.

\section{Geography of Capital Punishment}

The use of capital punishment in London and the Home Counties has been a focal point of investigation within the historiography focused upon England in the eighteenth and early nineteenth centuries. While lower execution rates in other provincial areas have been noted, this area of study has only recently been expanded upon using detailed quantitative analysis. ${ }^{21}$ The current study is based upon an analysis of the whole of Scotland and provides a national history of capital punishment whilst also demonstrating the importance of regional variations. Table 2.1 provides a breakdown of the total number of executions by decade and by circuit and Table 2.2 highlights the percentage of executions accounted for by convictions before the High Court in Edinburgh and the three circuit courts. Edinburgh consistently accounted for a notable percentage of the total executions. In contrast, the Southern Circuit of Ayr, Dumfries and Jedburgh typically made up a low percentage of the total

Table 2.1 Total executions by circuit

\begin{tabular}{lllllll}
\hline & Edinburgh & Northern & Western & Southern & Sheriff & Total \\
\hline $1740-1749$ & 9 & 19 & 5 & 0 & 5 & 38 \\
$1750-1759$ & 14 & 38 & 3 & 7 & 4 & 66 \\
$1760-1769$ & 7 & 14 & 6 & 4 & 0 & 31 \\
$1770-1779$ & 16 & 11 & 4 & 4 & 0 & 35 \\
$1780-1789$ & 29 & 14 & 20 & 14 & 2 & 79 \\
$1790-1799$ & 13 & 8 & 10 & 1 & 0 & 32 \\
$1800-1809$ & 17 & 6 & 9 & 5 & 0 & 37 \\
$1810-1819$ & 31 & 9 & 22 & 11 & 0 & 73 \\
$1820-1829$ & 29 & 10 & 35 & 7 & 0 & 81 \\
$1830-1834$ & 11 & 5 & 16 & 1 & 0 & 33 \\
Total & 176 & 134 & 130 & 54 & 11 & 505 \\
\hline
\end{tabular}

Source Figures compiled using the Justiciary Court records 
Table 2.2 Percentage of total executions made up by each circuit

\begin{tabular}{lllllll}
\hline & Edinburgh & Northern & Western & Southern & Sheriff & Total \\
\hline $1740-1749$ & 23.7 & 50 & 13.2 & 0 & 13.1 & 100 \\
$1750-1759$ & 21.2 & 57.6 & 4.6 & 10.6 & 6 & 100 \\
$1760-1769$ & 22.6 & 45.2 & 19.3 & 12.9 & 0 & 100 \\
$1770-1779$ & 45.7 & 31.5 & 11.4 & 11.4 & 0 & 100 \\
$1780-1789$ & 36.7 & 17.7 & 25.4 & 17.7 & 2.5 & 100 \\
$1790-1799$ & 40.6 & 25 & 31.3 & 3.1 & 0 & 100 \\
$1800-1809$ & 46 & 16.2 & 24.3 & 13.5 & 0 & 100 \\
$1810-1819$ & 42.5 & 12.3 & 30.2 & 15 & 0 & 100 \\
$1820-1829$ & 35.8 & 12.4 & 43.2 & 8.6 & 0 & 100 \\
$1830-1834$ & 33.3 & 15.2 & 48.5 & 3 & 0 & 100 \\
\hline
\end{tabular}

Source Figures compiled using the Justiciary Court records

number of executions across the period. In Ayr in April 1751, upon being informed that there was no criminal business for the district, "His Lordship expressed the pleasure it gave him to find so extensive an area in such quiet and peaceful disposition." ${ }^{22}$ This continued to be the case and, while the second and third decades of the nineteenth century saw an increase in court business in line with the wider Scottish context, the number of capital punishments remained relatively low. However, there were evident fluctuations in the percentages made up by the Western and Northern Circuits at different intervals in this period that require deeper analysis.

In questioning the geography of capital punishment, we must first investigate Scotland's demographic history in this period, namely the increase in population and, more importantly, where this was most concentrated. To trace the population figures for as much of the period as possible the analysis draws upon figures taken from the following sources. For the earlier part of the period Alexander Webster's account of 1755 is used. He was a minister in Edinburgh who based his population figures upon information he collected from 909 parishes. James Kyd published Webster's account along with the population data that became available following the first census in 1801 and at subsequent ten-yearly intervals. ${ }^{23}$ In addition, an enumeration of the census data taken in 1801, 1811 and 1821 was published in 1823 and is also useful. ${ }^{24}$ Prior to Webster's account, Scottish population totals are largely subject to educated approximation. Houston and Whyte put the late 
Table 2.3 Population of Scotland

\begin{tabular}{lll}
\hline & Total population & Rate of increase \% \\
\hline 1755 & $1,265,380$ & - \\
1801 & $1,608,420$ & 27.1 \\
1811 & $1,805,864$ & 12.3 \\
1821 & $2,091,521$ & 15.8 \\
1831 & $2,364,386$ & 13.0 \\
\hline
\end{tabular}

Source Table compiled by the author using population statistics provided in Kyd, Scottish Population Statistics, p. xvii

sixteenth-century figure at around 800,000 , rising to one million by 1700. ${ }^{25}$ Table 2.3 presents Scotland's population increase between 1755 and 1831, generally cited as a period of great and sustained growth. The population increased in most areas but the percentage and rate of growth differed markedly. For example, while the population of northern Scotland did increase, it was not at the same intense scale found in the country's central belt. ${ }^{26}$ For the purposes of this study we need to establish discernible links between population growth and distribution, urbanisation and the geography of capital punishment.

Investigations of Scotland have often pointed to the principal division, geographically but also culturally and linguistically, existing between the Highlands and the Lowlands. However, this is an oversimplified dichotomy when applied to Scottish population history. Geographically speaking the Lowlands included anything south of the Highland line, dividing the country from the Grampian Mountains to the south-east from the north-west Highlands. However, it was the central belt, including Scotland's largest cities of Glasgow to the west and Edinburgh to the east and their growing surrounding towns, rather than the southern border areas, that witnessed the greatest increase and concentration of population. During the eighteenth century, Scotland's urban growth was among the fastest in Europe. In 1750, it was ranked seventh in a table of Europe's most urbanised societies. By 1800 it was fourth and by 1850 it was second only to England and Wales. ${ }^{27}$ Edinburgh's population more than doubled from around 57,000 in 1755 to 138,000 in $1821 .{ }^{28}$ Tables 2.1 and 2.2 demonstrate that convictions before the High Court in Edinburgh consistently accounted for a sizeable proportion of executions throughout the period. However, Edinburgh did not contain as large a proportion of the urban population of Scotland as London 
did for England. By the early nineteenth century, the central belt was increasingly densely populated, with a growing proportion concentrated in Glasgow. The rise in prominence of west-central Scotland in terms of trade and population has been termed a "classic story of Scotland's economic history." 29 A focal point of activity was the areas surrounding the Clyde, an extensive maritime inlet that was well connected with the western seaways. In the early decades of the nineteenth century the urban expansion of Glasgow, to a point where it matched and then superseded that of Edinburgh in terms of population, correlated with the growing proportion of the total executions occurring in the area.

Scotland's changing urban demographic in the first third of the nineteenth century contributed to strained industrial and social relations and cyclical high unemployment as urban economies could not absorb the thousands of migrants that poured into these areas seeking regular employment. There were outbreaks of popular protest as the living standards of the urban poor deteriorated. ${ }^{30}$ In terms of contextualising the use of capital punishment, the impact of rapid urbanisation is clear in places like Glasgow. There was very little criminal business brought before the Western Circuit in the 1740s and 1750s when whole years passed with no cases at all. In 1764, the judge at Glasgow expressed satisfaction that there were no criminal cases for trial and praised "the civilised state of this part of the country." 31 However, in December 1828, provisions were made for an additional sitting of the court due to the sheer volume of cases being brought before it. By the 1820s and 1830s the Western Circuit, predominantly cases from Glasgow, sent more criminals to the scaffold than the High Court in Edinburgh, accounting for $43.2 \%$ of the total executions in the 1820 s and $48.5 \%$ in the early 1830 s. In combining Webster's 1755 account and the enumerated data for the first three censuses with the execution figures gathered for this study it is possible to calculate the number of executions per 100,000 head of Scotland's population across Edinburgh and the three circuits in 1755 and the early decades of the nineteenth century. The findings are provided in Table 2.4. The figure for Edinburgh consistently remained above 1.0 execution per 100,000 head of population. However, the figures for the Western Circuit present a different pattern which is linked to the area's rapidly increasing population and rising prominence as an urban centre. Glasgow's population in 1755 was about 32,000 and by 1801 it was 77,385 compared to Edinburgh's 82,560. By 1821 Glasgow had overtaken with over 147,000 inhabitants compared to Edinburgh's $138,000 .{ }^{32}$ Chapter 3 will demonstrate that with 
Table 2.4 Executions per 100,000 head of Scotland's population

\begin{tabular}{llllll}
\hline & Scotland & Edinburgh & Northern & Western & Southern \\
\hline $1750-1759$ & 5.2 & 1.1 & 3.0 & 0.2 & 0.6 \\
$1800-1809$ & 2.3 & 1.1 & 0.4 & 0.6 & 0.3 \\
$1810-1819$ & 4.0 & 1.7 & 0.5 & 1.2 & 0.6 \\
$1820-1829$ & 3.9 & 1.4 & 0.5 & 1.7 & 0.3 \\
\hline
\end{tabular}

Source Figures compiled from Justiciary Court records and the population statistics provided in Kyd, Scottish Population Statistics, p. xvii and the Enumeration of the Inhabitants of Scotland (Glasgow: 1823)

this increasingly dense urban population came an increase in the use of capital punishment, particularly for property offences, and more intense debates in the Scottish newspapers over how to rectify this problem.

Between the 1740s and the 1760s, the Northern Circuit accounted for the highest percentage of executions, with a peak of $57.6 \%$ in the $1750 \mathrm{~s}$, a period in which executions occurred at a rate of 3.0 per 100,000 head of Scotland's population (Table 2.4), an area to be further investigated in Chap. 3. However, despite covering a large geographical area, capital convictions following trials before the Northern Circuit had fallen by the 1770s, and by the early nineteenth century the figure was markedly lower still. In 1818 the Scots Magazine commented, to the credit of the city of Aberdeen and its surrounding counties, that there had been only three executions conducted there in the last 27 years. Although two people had forfeited their lives in 1818 alone, it was further remarked that the area was certainly not "the forerunner of that increase in crime, by which many parts of the United Kingdom are, at this period, lamentably disgusted." 33 One potential explanation for this may be that, despite experiencing a population increase, northern Scotland was not growing at anywhere near the rate experienced in the central belt. In addition, the increased numbers of executions in the late 1740s and 1750s can be placed within the wider context of the aftermath of the 1745 Jacobite Rebellion and government attempts to establish long-term stability. By the late eighteenth century, the area had ceased to be a concern regarding any potential serious uprising.

The quantitative analysis provided in this chapter includes all offenders who were convicted of a capital offence. However, we must note that not all offenders who were found guilty ended up facing the death sentence. Instead, the implementation of criminal justice in this period was 
a multi-staged decision-making process that was subject to discretion. In addition, we must acknowledge that the low numbers of executions in Scotland, particularly when compared to England, may not be due solely to low crime rates and that the figures could also have been affected by more deliberate customary, and largely unrecorded, practices of crime control. In the late eighteenth century, MacLaurin recalled former times when the government and the monarch were too weak to impose central powers in areas of northern Scotland. ${ }^{34}$ The abolition of Heritable Jurisdictions in 1747 was intended to combat this and to act as the conclusion to an already declining complex system in favour of vesting judicial power in the hands of the central criminal courts. However, the very low numbers of offenders brought before the circuit courts, particularly from certain areas in northern Scotland, suggest that extra-judicial practices persisted in this period to some extent. For example, the Northern Circuit court sitting at Inverness was attended by the sheriff deputies of Inverness, Ross, Elgin, Nairn, Cromarty, Sutherland, Caithness, Shetland and Orkney, although very few offenders from the latter four areas were among those capitally convicted. In addition, the Sheriff Depute of Shetland and Orkney rarely attended and, while the court instructed the clerk to write to him insisting that he attend, and reported his continued absence to the High Court in Edinburgh, the situation was not rectified. ${ }^{35}$ Therefore, while this study has based its arguments upon a systematic gathering and analysis of the available records, it acknowledges that the true extent of the commission of potentially capital crimes that never made it before the courts cannot be quantified here.

\section{Capital Punishment and the Scottish Murderer}

Within the black catalogue of offences that carried a capital charge, the crime of murder had long since been chosen for exemplary punishment. Part II of this volume will demonstrate that historically murderers could be subjected to prolonged and sanguine execution spectacles involving both the pre-mortem and post-mortem evisceration of the body. Between 1740 and 1834 there were 160 executions for the crime of murder, 124 men and 36 women. Of the total 505 executions, murders accounted for $31.7 \%$. Table 2.5 shows that the number of executions for murder did not fluctuate to the same extent as those for property offences. Throughout most of this period murder accounted for around one third of the total executions until the 1830s, when there was a lesser recourse 
Table 2.5 Executions broken down by category of offence

\begin{tabular}{llllllllll}
\hline & Murder & \multicolumn{3}{c}{ Property } & \multicolumn{3}{c}{ Other } & \multicolumn{3}{c}{ Total } \\
\cline { 2 - 9 } & No. of Ex & $(\%)$ & No. of Ex & $(\%)$ & No. of Ex & $(\%)$ & No. of $E x$ & $(\%)$ \\
\hline $1740-1749$ & 20 & 52.6 & 16 & 42.1 & 2 & 5.3 & 38 & 100 \\
$1750-1759$ & 22 & 33.4 & 43 & 65.1 & 1 & 1.5 & 66 & 100 \\
$1760-1769$ & 17 & 54.9 & 13 & 41.9 & 1 & 3.2 & 31 & 100 \\
$1770-1779$ & 11 & 31.4 & 24 & 68.6 & 0 & 0 & 35 & 100 \\
$1780-1789$ & 6 & 7.6 & 73 & 92.4 & 0 & 0 & 79 & 100 \\
$1790-1799$ & 10 & 31.3 & 21 & 65.6 & 1 & 3.1 & 32 & 100 \\
$1800-1809$ & 14 & 37.8 & 22 & 59.5 & 1 & 2.7 & 37 & 100 \\
$1810-1819$ & 13 & 17.8 & 59 & 80.8 & 1 & 1.4 & 73 & 100 \\
$1820-1829$ & 25 & 30.9 & 52 & 64.2 & 4 & 4.9 & 81 & 100 \\
$1830-1834$ & 22 & 66.7 & 9 & 27.3 & 2 & 6 & 33 & 100 \\
Total & 160 & & 332 & & 13 & & 505 & \\
\hline
\end{tabular}

Source Figures compiled using the Justiciary Court records

to the death sentence for some property offences, and the figure subsequently rose to over two thirds of the total executions. Table 2.6 shows the proportion of all capitally condemned offenders who were executed between 1740 and 1834. Apart from the figures for the 1820s, which were affected by remissions following the 1820 treason trials, the percentage throughout the period remained between 60 and 80\%. ${ }^{36}$ However, when the proportion of capitally convicted murderers who were subsequently executed is examined (Table 2.7), the figures are almost consistently higher in comparison to overall capital convictions. This demonstrates that a capital conviction for murder was the most likely to result in an execution.

When investigating the crime of murder, an analysis of the victims and their relationship to the perpetrator can offer a valuable insight into the circumstances surrounding the commission of the offence in Scotland. In his study of homicide in eighteenth-century Scotland, Knox based his findings upon evidence gathered from 433 indicted cases between 1700 and 1799 . He found that intimate killings, the murdering of people known to the victim including relatives and workmates, consistently accounted for between 45 and $49 \%$ of the total cases. ${ }^{37}$ While this conclusion is broadly reinforced here, the current study has identified a distinct gender difference in its examination of the relationship of capitally convicted murderers to their victims. In terms of male murderers, the 
Table 2.6 Proportion of capitally convicted offenders executed

\begin{tabular}{lllllll}
\hline & Executions & \multicolumn{3}{c}{ Remissions No. \% } & \multicolumn{3}{c}{ Total No. \% } \\
\cline { 2 - 7 } & No. & $(\%)$ & No. & $(\%)$ & No. & $(\%)$ \\
\hline $1740-1749$ & 38 & 79.2 & 10 & 20.8 & 48 & 100 \\
$1750-1759$ & 66 & 81.5 & 15 & 18.5 & 81 & 100 \\
$1760-1769$ & 31 & 70.5 & 13 & 29.5 & 44 & 100 \\
$1770-1779$ & 35 & 64.8 & 19 & 35.2 & 54 & 100 \\
$1780-1789$ & 79 & 65.8 & 41 & 34.2 & 120 & 100 \\
$1790-1799$ & 32 & 60.4 & 21 & 39.6 & 53 & 100 \\
$1800-1809$ & 37 & 62.7 & 22 & 37.3 & 59 & 100 \\
$1810-1819$ & 73 & 62.4 & 44 & 37.6 & 117 & 100 \\
$1820-1829$ & 81 & 46.6 & 93 & 53.4 & 174 & 100 \\
$1830-1834$ & 33 & 70.2 & 14 & 29.8 & 47 & 100 \\
Total & 505 & & 292 & & 797 & \\
\hline
\end{tabular}

Source Figures compiled using Justiciary Court records and Home Office papers, series HOl04, folios $1-8$

Table 2.7 Proportion of offenders capitally convicted for murder executed

\begin{tabular}{|c|c|c|c|c|c|}
\hline & \multicolumn{2}{|c|}{ Executions } & \multicolumn{2}{|c|}{ Remissions } & \multirow[t]{2}{*}{ Total } \\
\hline & No. & $(\%)$ & No. & $(\%)$ & \\
\hline $1740-1749$ & 20 & 87 & 3 & 13 & 23 \\
\hline $1750-1759$ & 22 & 81.5 & 5 & 18.5 & 27 \\
\hline $1760-1769$ & 17 & 74 & 6 & 26 & 23 \\
\hline $1770-1779$ & 11 & 61 & 7 & 39 & 18 \\
\hline $1780-1789$ & 6 & 85.7 & 1 & 14.3 & 7 \\
\hline $1790-1799$ & 10 & 77 & 3 & 23 & 13 \\
\hline $1800-1809$ & 14 & 93 & 1 & 7 & 15 \\
\hline $1810-1819$ & 13 & 81.3 & 3 & 18.7 & 16 \\
\hline $1820-1829$ & 25 & 83.3 & 5 & 16.7 & 30 \\
\hline $1830-1834$ & 22 & 78.6 & 6 & 21.4 & 28 \\
\hline Total & 160 & & 40 & & 200 \\
\hline
\end{tabular}

Source Figures compiled using Justiciary Court records and Home Office papers, series $\mathrm{HOl} 04$, folios 1-8

victim was either a family member or a lover in $41 \%$ of the total 124 cases. In 31 of the cases the victim was their wife and most killings had occurred within the confines of the home. A further $18 \%$ of the total cases are accounted for by men who had murdered acquaintances or 
people known to them, including work colleagues, and $41 \%$ of cases in which the victim was a stranger. Comparatively, of the total 36 women executed for murder between 1740 and 1834 , in $30(83 \%)$ of the cases the victim was a family member, most often their own child.

Chapter 4 will provide a more extensive analysis of the capital punishment of Scottish female murderers, including those convicted of infanticide. Women accounted for an overwhelming majority of the total perpetrators brought before the Scottish courts for the crime of child murder, as in other European countries, and there were discernible similarities in several cases, notably the fact that the victim was an illegitimate infant. ${ }^{38}$ An interesting comparison can be drawn here with legal responses towards the handful of men charged with the crime. For example, seven men were executed for the murder of a lover and in most instances the woman had either recently given birth to an illegitimate child or had revealed a pregnancy, and in one case the child was also murdered. John MacMillan was convicted of the murder of Barbara McKinnel in 1810. She was six months pregnant with his child when he gave her muriate of mercury with the intention of aborting the child. Although in his defence he claimed that he had only tried to conceal her shame in procuring the poison for her, he was capitally convicted. ${ }^{39}$ Despite the apparent lack of desire to kill Barbara, the intent to kill the child was proof enough of premeditation to send him to the gallows. Similar motivations can be found in the cases of the five men who were executed for the murder of their own child, all of whom appeared to have been illegitimate. Unlike in some of the cases examined in this study, where young, single women had killed their illegitimate child, there was no apparent sympathy for these men and their desire to conceal an affair or to avoid taking financial responsibility for their child served to further aggravate their guilt.

Chapter 4 will demonstrate that women were rarely capitally convicted for the murder of wider acquaintances or strangers and their crimes were almost exclusively committed against close relatives and their children. This is largely reflective of the predominantly domestic roles of women in this period, either as wives and mothers in their own homes, or as domestic servants. Comparatively, in $18 \%$ of male murder cases their victims were acquaintances or work colleagues and the crimes had been committed outside of the domestic setting; in a further $41 \%$ of the cases the victims were strangers. In over half of these cases the murders had been linked to or charged along with property offences such as theft and robbery which 
served to aggravate their case in the eyes of the courts. In some, premeditation was evident due to the location of the crimes, being upon roads or less-frequented areas. William Doig had acquainted himself in Perth with fellow travelling chapman, 14-year-old Peter Maxton, with the intent of murdering him and stealing $£ 9$ worth of goods. The body was left in a mass of woodland and was not discovered for seven weeks due to the remoteness of the location. ${ }^{40}$ The fear of murders that occurred during robberies became a potent theme in the courts and the press coverage of crime in the early nineteenth century, and will be expanded upon in Chap. 3. The remaining cases of male murderers were predominantly made up of drunken disputes or followed fights between the victim and the murderer who were, in some cases, work colleagues and friends.

In cases of murder, intent, often referred to as malice in the court records, had to be proven to achieve a murder conviction, rather than the lesser and non-capital crime of culpable homicide. In terms of murders committed by men where the victims were also men, especially those that occurred during fights, there were often debates surrounding the issue of provocation and the proving of premeditation. If it was proven that the accused had started the fight, the charge would be murder rather than culpable homicide. In 1802 George Lindsay was executed after he and John Allan had publicly argued and when Lindsay returned to the place where they both lived he picked up a knife and waited for Allan to return before stabbing him. ${ }^{41} \mathrm{~A}$ similar case occurred in 1814 when John McManus had previously fought with Allan Hutton before returning to his lodgings to procure his gun and shoot Hutton dead. ${ }^{42}$ These cases, and numerous others like them, resulted in murder charges, rather than the lesser charge of culpable homicide, as the accused had been the principal actor in the altercations and, in the cases of Lindsay and McManus, had not acted in the heat of the moment. Instead, their crime was proven to have been premeditated as they had left the initial fight to procure a lethal weapon. What is clear is that, although there were debates in the courts over proving murder, once an offender was convicted they would likely face the hangman's noose throughout this period. However, the use of capital punishment against property offenders was not subject to the same level of consistency. Indeed, there were notable fluctuations not only in the sheer number of offenders who suffered the death sentence for their crimes but also in the legal and public responses to certain types of property crime at different intervals. 


\section{Capital Punishment and Scottish Property Offenders}

During the period 1740-1834 property offences accounted for 332 $(65.7 \%)$ of the total 505 executions. The fluctuations in Scotland's use of capital punishment across this period were largely attributable to executions and pardons for property offences. It is worth noting here that, of the total 47 women executed in Scotland in this period, only 11 had been convicted of a property offence and thus women accounted for just $3 \%$ of the total 332 malefactors executed. Although the sheer numbers were less, the proportion of capitally convicted property offenders who were women was comparable to the figure found in England. ${ }^{43}$ While their numbers are included in this analysis and in the examination of the fluctuations in capital punishment to be provided in Chap. 3, the legal and public responses to female property offenders are more extensively and qualitatively explored in Chap. 4 in order to highlight the factors that potentially impacted upon the use of the death sentence for these women.

As previously established, capital convictions for murder were statistically more likely to result in an execution (see Tables 2.6, 2.7), and the proportion of capitally convicted murderers who were executed was almost consistently higher than the figure for capitally convicted offenders overall. Comparatively, Table 2.8 shows that the proportion of capitally convicted property offenders who were subsequently executed fluctuated to a greater extent, and more closely mirrored the general figure. For example, $82.7 \%$ of capitally convicted property offenders were executed in the mid-eighteenth century, compared to only $44.4 \%$ in the 1820 s.

Although this study focuses primarily upon the cases that made it before the central criminal courts and resulted in capital convictions, it also explores the role of discretion in deciding who faced a capital charge for property offences, particularly on the part of the judges and the prosecution. As the accused was able to petition the court prior to the start of potentially capital trials, and the judges could exercise discretion in restricting the libel before the jury was sworn in, offenders would not always face a capital punishment even if the jury returned a guilty verdict. In addition, Table 2.9 shows that, when broken down by decade and category of offence, pardons for property crimes accounted for two thirds or more of the total number of pardons given. The role of discretion in the decision-making process was more marked in cases of property offences 
Table 2.8 Proportion of offenders capitally convicted for property offences executed

\begin{tabular}{lcrrrr}
\hline & Executions & \multicolumn{3}{c}{ Remissions } & Total \\
\cline { 2 - 5 } & No. & $(\%)$ & No. & $(\%)$ & \\
\hline $1740-1749$ & 16 & 72.7 & 6 & 27.3 & 22 \\
$1750-1759$ & 43 & 82.7 & 9 & 17.3 & 52 \\
$1760-1769$ & 13 & 68.4 & 6 & 31.6 & 19 \\
$1770-1779$ & 24 & 68.6 & 11 & 31.4 & 35 \\
$1780-1789$ & 73 & 65.2 & 39 & 34.8 & 112 \\
$1790-1799$ & 21 & 61.8 & 13 & 38.2 & 34 \\
$1800-1809$ & 22 & 53.7 & 19 & 46.3 & 41 \\
$1810-1819$ & 59 & 60.2 & 39 & 39.8 & 98 \\
$1820-1829$ & 52 & 44.4 & 65 & 55.6 & 117 \\
$1830-1834$ & 9 & 64.3 & 5 & 35.7 & 14 \\
Total & 332 & & 212 & & 544 \\
\hline
\end{tabular}

Source Figures compiled using Justiciary Court records and Home Office papers, series $\mathrm{HO} 104$, folios $1-8$

than murder and could go some way to determining the level of capital punishment for certain property offences depending upon factors such as geographical context, the age and gender of offenders and the public discourse surrounding crime.

Scotland did not have the number of capital statutes that existed in England at this time and the list of thefts punishable by death in virtue of special statutes was very short in comparison. In addition, Hume argued that, as theft was not a crime of one invariable character, the Scottish judges had a great degree of discretion in deciding upon suitable punishments based upon individual circumstances. ${ }^{44}$ Thefts related to the mail were crimes at common law but were also covered by a Scottish act passed in 1690 'Anent stealing of the packet'. The legislation passed in Westminster in 1767 (7 Geo III c.50) also included Scotland. Despite this, executions for the crime were still relatively low with only 12 in this period. However, in the case of Kenneth Leal in 1773, exemplary punishment was used as he was executed and hung in chains at the spot where he robbed a post boy. ${ }^{45}$ Along with theft relating to the mail, Hume only cited one further specific category of theft covered by special statute passed in 1744 (18 Geo II c.27), namely theft of linen, cotton and calico to the value of 10 shillings from a bleaching field. ${ }^{46}$ Another form of capital theft in Scotland was known as plagium, which involved the theft of a child. However, there were only three capital convictions 
Table 2.9 Pardons broken down by category of offence

\begin{tabular}{lllllllll}
\hline & Murder & \multicolumn{3}{c}{ Property } & & Other & \multicolumn{3}{c}{ Total } \\
\hline & No. & $(\%)$ & No. & $(\%)$ & No. & $(\%)$ & No. & $(\%)$ \\
\hline $1740-1749$ & 3 & 30 & 6 & 60 & 1 & 10 & 10 & 100 \\
$1750-1759$ & 5 & 33.3 & 9 & 60 & 1 & 6.7 & 15 & 100 \\
$1760-1769$ & 6 & 46.2 & 6 & 46.2 & 1 & 7.6 & 13 & 100 \\
$1770-1779$ & 7 & 36.8 & 11 & 57.9 & 1 & 5.3 & 19 & 100 \\
$1780-1789$ & 1 & 2.4 & 39 & 95.2 & 1 & 2.4 & 41 & 100 \\
$1790-1799$ & 3 & 14.3 & 13 & 61.9 & 5 & 23.8 & 21 & 100 \\
$1800-1809$ & 1 & 4.5 & 19 & 86.4 & 2 & 9.1 & 22 & 100 \\
$1810-1819$ & 3 & 6.9 & 39 & 88.6 & 2 & 4.5 & 44 & 100 \\
$1820-1829$ & 5 & 5.4 & 65 & 69.9 & 23 & 24.7 & 93 & 100 \\
$1830-1834$ & 6 & 42.9 & 5 & 35.7 & 3 & 21.4 & 14 & 100 \\
Total & 40 & & 212 & & 40 & & 292 & \\
\hline
\end{tabular}

Source Figures compiled using Home Office papers, series HOl04, folios 1-8

of women for the crime and they were all subsequently conditionally pardoned.

Housebreaking was the most frequent aggravation of theft and was capital regardless of the value of the items stolen throughout much of this period, unless the level of punishment had been restricted prior to the commencement of the trial. The crime of housebreaking and theft, as charged in the courts, made up about one fifth of the total executions in this period and almost one third of the total executions for property offences. However, due to the potential for judicial discretion in allowing the accused to petition the court or for the court to restrict the libel before the start of the trial, hundreds of offenders avoided facing a capital punishment. At times of increased executions, notably the 1780s, capital convictions for the crime of housebreaking and theft increased. The outbreak of the American War of Independence (1775-1783) ended the penal option of transporting offenders to America and the British government did not immediately decide upon Australia as an alternative destination. ${ }^{47}$ Chapter 3 will argue that the increase in executions in the 1780s was due, in large part, to the lack of a sufficiently severe secondary penal option and thus the limiting of the courts' ability to restrict the level of punishment to be meted out to those convicted. The chapter will also demonstrate that there was not a desire to send unprecedented numbers to the scaffold and that the proportion of capitally convicted property offenders who were executed remained relatively consistent. 
After housebreaking and theft, robbery made up the second largest proportion of executions for property offences, accounting for $34 \%$ of the total. ${ }^{48}$ In England, robbery had been regarded as an indicator of the prevalence of crime more generally in the eighteenth century. In 1751 Henry Fielding warned of the frequency of the crime in London and stated that, if unchecked, the already flagrant increase in robberies would be liable to reach even greater heights. ${ }^{49}$ However, in Scotland, with the exception of the Highlands, more pressing concerns over the prevalence of the crime of robbery were not as evident in the mideighteenth century. In February 1747 three men were indicted before the High Court in Edinburgh for violently assaulting His Majesty's subjects with lethal weapons and robbing them of money upon the public highways. Their defence counsel argued that the crime of highway robbery should be punished with less severity in Scotland than in England "where the punishment was always capital." He went on to argue that the crime rarely happened in Scotland and it was a just principle that the severity of the law should be proportional to how often the crime was committed. The men petitioned the court, which was consented to by the Advocate Depute, and they were banished to America for life instead of standing trial and facing a capital punishment. ${ }^{50}$ This case not only demonstrates the discretionary powers of the courts, it also reveals how attitudes towards the perceived prevalence of the crime could affect legal responses to it in the decision-making process. The reluctance to pursue a capital charge for some offenders in Scotland is comparable to practices in Wales where both petty and grand juries made marked efforts to prevent offenders being found guilty of robbery indictments. Therefore, in the wider British context, Scottish responses to robbery in the mideighteenth century, with the notable caveat of the Highlands, reinforce the centre-periphery dichotomy established by King and Ward in their study of the capital punishment of property offences. ${ }^{51}$

The number of executions for robbery had been relatively low until the 1780s, especially when compared to England, and there was at least a degree of awareness of this, as evidenced in the above case. However, by the second decade of the nineteenth century, robbery had become a greater concern in the Scottish courts and the newspapers, a topic that will be further discussed in Chap. 3. In terms of the geography of the crime, the predominant number of capital convictions occurred in Scotland's central belt, a fact that was evident in the parliamentary returns for the years $1811-1814 .^{52}$ In gathering and analysing the data 
presented in the 1819 Report from the Select Committee on Criminal Laws, Emsley demonstrated that for London and Middlesex, between 1775 and 1784, the percentage of people executed following a capital conviction for highway robbery was $38.9 \%$. By the early nineteenth century this had fallen to $8.6 \%{ }^{53}$ Comparatively, in Scotland in the 1780 s, during a peak decade in the overall numbers sent to the scaffold, $58.3 \%$ of those capitally convicted for robbery were executed. While this subsequently declined slightly, by the second decade of the nineteenth century it had risen again and $84 \%$ of offenders capitally convicted for robbery or the crime of stouthrief, which was sometimes charged synonymously with robbery in the early nineteenth century and involved the use of violence in a dwelling place, were executed. Chapter 3 will examine this continued high proportion of executions to capital convictions in more detail and present some potential explanations for it.

There were 49 executions for theft of cattle, horses or sheep in this period. Fourteen of the cases occurred between 1746 and 1755 following trials before the Northern Circuit, this being the highest concentration of executions for the crime in any decade across this period. When breaking down the numbers of executions by decade, those for cattle, horse or sheep theft present almost a reverse pattern to the figures for other property offences, notably robbery, as there were only seven people executed for the crime following the turn of the nineteenth century. Towards the end of the eighteenth century the charges were often restricted to a lesser offence and thus not punished capitally. For example, in Inverness in May 1774, three men had been indicted for cattle theft but were found guilty only of slaughtering the cows in question. ${ }^{54}$ By the nineteenth century it was only in cases of excessive theft, such as that of James Ritchie who had stolen 30 sheep from the parks of Gordon Castle, where a capital punishment was passed. ${ }^{55}$ A return of the number of persons brought to trial for crimes of a potentially capital nature in Scotland between 1827 and 1832 was presented to Parliament in 1832. The total number of people charged with various forms of theft, including that of horses and cattle as well as theft aggravated by housebreaking, was 1076 . However, in all but 24 of these cases, the charge was restricted so the criminal would not face a capital trial. ${ }^{56}$ Of these 24 cases, there were 12 capital convictions but only three executions. This demonstrates that, by the 1830s, property offences were sending fewer criminals to the scaffold despite Alison's observation in 1832 that "probably a greater number of cases have been tried since the peace of 1815 than from the institution of the Court of Justiciary down to that time." 57 
A reading of the court records themselves also reflects the swell in the sheer volume of cases. An increase in criminality may have occurred, particularly in Scotland's rapidly industrialising central belt, or policing and prosecution methods may have become more efficient, thus bringing more offenders to justice. However, what is clear is that the figures demonstrate the importance of the discretionary power of the courts, particularly that of the judges, to limit the level of punishment meted out.

In England, upwards of 60 capital statutes were passed in the eighteenth century related to the crime of forgery. ${ }^{58}$ Furthermore, McGowen stated that, along with murder, a capital conviction for the crime of forgery in the eighteenth century was the most likely to see an offender subsequently executed in England. ${ }^{59}$ However, many of the capital statutes that made up the 'Bloody Code' were not extended to Scotland. In turn, there were only 26 men executed for the crime of forgery in Scotland in this period and a further 18 men and two women who had been capitally convicted for the crime but subsequently pardoned. Comparatively, in England between 1775 and 1815, Emsley gathered the figures for London and Middlesex as well as the Home Counties, Western and Norfolk circuits and found that 366 people were capitally convicted for forgery and, of these, 204 were executed. ${ }^{60}$ During the trial of George McKerracher in 1788, despite the fact that he had forged and uttered (distributed) $£ 48$ and $£ 49$ bills of exchange, his defence argued that no damage had been sustained by any individual and thus asked for a restriction of the charge. However, this was refused and he was found guilty and sentenced to be executed in Stirling in March $1788 .{ }^{61}$ When sending his report of the trial proceedings to the Home Office, the Lord Advocate, Ilay Campbell, stated that there were no favourable circumstances in McKerracher's case. He further asserted that forgery was as much a capital crime in Scotland as in England and called for an example to be made with his execution. ${ }^{62}$ The belief that the crime would not be punished with death in Scotland was also apparent among others capitally convicted, even as they mounted the scaffold. At his execution in 1785 Neil Mclean was described as having "laboured under a misconception of the nature of his crime" and the severity of the punishment attached to it. ${ }^{63}$ These cases are examples of the discretion exercised in the Scottish courts in response to the crime of forgery, perhaps due to their greater use of the common law as opposed to the statutes that made up the 'Bloody Code'.

There were two main aggravations evident in cases where offenders were capitally punished for the crime of forgery. The first was the 
magnitude of the crime. David Reid had forged Bank of Scotland notes and uttered them in various areas including Edinburgh, Dumfries, Kirkcudbright and Wigtown in $1780 .{ }^{64}$ Similarly, William Mackay had committed the crime in Ayr, Lanark and Renfrew. Although the jury only found him guilty of one of the charges, when passing the death sentence Lord Gillies stated that even if the prisoner had issued only one forged note, it was the same as if he had issued 50 of them. ${ }^{65}$ The second aggravation in some of the cases was the status of the condemned. In cases of forgery, unlike in most other crimes, if a person was educated, a man of property, or held a position of trust their offence was aggravated. William Evans had been an overseer on the estate of the Duke of Portland before his execution in 1816 for forging bills of exchange. ${ }^{66}$ Malcolm Gillespie was an excise officer in Aberdeen when he was convicted of forging in excess of $£ 200$ in bills of exchange. ${ }^{67}$ Following his execution in 1800 for forging and uttering notes of Carrick, Brown and Company, bankers in Glasgow, Samuel Bell was described as having been an industrious man of property. ${ }^{68}$ Following his conviction for forgery in 1797 Millesius Roderick Maccullan was reported to have been bred in polite life and to have had the manners of a gentleman. Despite petitions from various respectable quarters in Edinburgh he was executed. ${ }^{69}$ An article in the Chester Courant cited similarities between his case and the heavily reported upon English case of Dr William Dodd, who had been executed at Tyburn for forgery in 1777, and stated that forgery was a dangerous crime and was not to be forgiven regardless of the status of the offender. ${ }^{70}$

By the late 1820s there were calls to abolish the death penalty for the crime of forgery due to the increasing difficulties in securing capital convictions. ${ }^{71}$ In England and Wales between 1820 and 1829, Radzinowicz noted that of 733 people capitally convicted for forgery, only 64 were executed. ${ }^{72}$ In Scotland in the 1820s there were six executions but nine pardons for the crime. The Edinburgh Review, a magazine edited by young Whig lawyers with support from men such as Francis Jeffrey and Henry Cockburn, argued for the promotion of Whig reforms to Scots law in the early nineteenth century. Despite sitting in an English seat in the Commons, Henry Brougham was one of the most prominent contributors to the Review and wrote in 1831 on the abolition of the death sentence for the crime of forgery. He argued that the death sentence was harder to secure for the crime and thus it was logical to legislate for a less 
severe, but more certain, punishment. ${ }^{73}$ In this sense the situation north and south of the border was comparable and thus the death sentence was abolished for the crime of forgery in England and Wales and Scotland by an act passed in 1832 ( $2 \& 3$ Will. IV c.123).

\section{CONCLUSION}

To conclude, although Scotland's lesser use of the gallows has been acknowledged by historians, the subject has thus far remained largely unexplored. To quote Crowther, Scotland is a country with "no criminal record." $"$ This study seeks to provide this history through its examination of Scotland's use of capital punishment. The journey of an offender from the commission of their crimes to their suffering for them upon the scaffold was subject to a discretionary and multi-staged decision-making process. Although this chapter, and the book more widely, is focused upon those who were brought before the central criminal courts and capitally convicted, it has acknowledged the importance of pre-trial processes such as the building up of evidence and the decision of the courts to pursue capital charges or not. It has addressed the theme of judicial discretion in Scotland and questioned how these factors potentially impacted upon the number of people who were tried on a capital charge. Furthermore, it has explored crucial long-term patterns and trends in the use of capital punishment for certain crimes to contextualise the subsequent chapters of this book.

The chapter has demonstrated the importance of the nuances of the Scottish legal system and court procedures that impacted upon the country's use of the death sentence. It has offered notable comparisons between the Scottish and the English experience of capital punishment and has provided a fresh perspective from which to view relations between the two countries in the wake of the 1707 Union. What is clear is that, while there were discernible similarities in the use of the death sentence north and south of the border, the Scottish experience cannot be assimilated into the English historiography. Instead, it provides a unique perspective that both reinforces and yet challenges the broader eighteenth- and nineteenth-century penal narrative, particularly when we examine the drivers behind the use of the death sentence and the judicial responses to it during three focal periods in Scotland's capital punishment history. 


\section{Notes}

1. V. A. C. Gatrell, The Hanging Tree: Execution and the English People 1770-1868 (Oxford: Oxford University Press, 1994), ix.

2. M. Anne Crowther, "Scotland; A Country with No Criminal Record", Scottish Economic and Social History 12 (1992): 82-85, 82.

3. See Lindsay Farmer, Criminal Law, Tradition and Legal Order: Crime and the Genius of Scots Law, 1747 to the Present (Cambridge: Cambridge University Press, 1997); M. Anne Crowther, "Crime, Prosecution and Mercy: English Influence and Scottish Practice in the Early Nineteenth Century", in Kingdom's United? Great Britain and Ireland Since 1500, ed. by S. J. Connolly, 225-238, Dublin: Four Courts Press, 1999.

4. Leon Radzinowicz, A History of English Criminal Law Volume 1. The Movement for Reform (London: Stevens and Sons, 1948), 35.

5. Douglas Hay, "Property, Authority and the Criminal Law", in Albion's Fatal Tree: Crime and Society in Eighteenth-Century England, ed. by Douglas Hay, Peter Linebaugh, John G. Rule, E. P. Thomson and Cal Winslow, 17-63, 51, London: Allen Lane, 1975. Peter Linebaugh similarly stressed the importance of Tyburn hangings in protecting property in The London Hanged: Crime and Civil Society in the Eighteenth Century (London: Allen Lane, 1991).

6. John H. Langbein, “Albion's Fatal Flaws”, Past and Present 98 (1983): 96-120, 118.

7. Peter King, Crime, Justice and Discretion in England 1740-1820 (Oxford: Oxford University Press, 2000), 1.

8. See John Louthian, The Form of Process before the Court of Justiciary in Scotland (Edinburgh: 1732); Henry Home, Lord Kames, Statute Law of Scotland Abridged with Historical Notes (Edinburgh: 1757); David Hume, Commentaries on the Law of Scotland Respecting Crimes Volumes 1 and 2 (Edinburgh: Bell and Bradfute, 1819); Sir Archibald Alison, Principles of the Criminal Law of Scotland (Edinburgh: William Blackwood, 1832).

9. James Dalrymple, Viscount of Stair, Institutions of the Law of Scotland (Edinburgh: first published 1681, this edition 1832), vi.

10. Alison, Principles of the Criminal Law of Scotland, 625.

11. For a more detailed account of the role of the procurator fiscal in building up evidence, see Crowther, "Crime, Prosecution and Mercy", 225-238.

12. For example, in his study of the Netherlands, Spierenburg charted the development in the criminal law of a new procedure in criminal trials where the inquisitorial method of prosecution gradually superseded the older accusatory procedure. He added that, while the accusatory procedure had favoured the accused, the rules of the inquisitorial procedure 
favoured those prosecuting them. In addition, the latter procedure meant that, in more serious crimes, the court could take the initiative and begin an investigation and the court's prosecutor could act as plaintiff. For more detail, see Pieter Spierenburg, The Spectacle of Suffering: Executions and the Evolution of Repression: From a Preindustrial Metropolis to the European Experience (Cambridge: Cambridge University Press, 1984), 8-10.

13. Hume, Commentaries, Vol. 1, 9.

14. Anne-Marie Kilday, "Contemplating the Evil Within: Examining Attitudes to Criminality in Scotland 1700-1840", in Crime, Courtrooms and the Public Sphere in Britain 1700-1850, ed. by David Lemmings, 147-166, 154, Surrey: Ashgate Publishing, 2012.

15. NAS JC8/12/129.

16. Hume, Commentaries, Vol. 1, 5 .

17. Stephen J. Davies, "The Courts and the Scottish Legal System 16001747: The Case of Stirlingshire", in Crime and the Law: The Social History of Crime in Western Europe since 1500, ed. by V. A. C. Gatrell, Bruce Lenman and Geoffrey Parker, 120-154, 149, London: Europa Publications, 1980.

18. For a more detailed guide of the Justiciary Court trial process, see Louthian, Form of Process before the Court of Justiciary.

19. For more detail on the English pre-trial process see J. M. Beattie, Crime and the Courts in England 1660-1800 (Oxford: Oxford University Press, 1986), 318.

20. The executions for treason following the 1745 Jacobite Rebellion were not included in these figures as the rebels were tried and executed by commissions of Oyer and Terminer in England. However, the convictions following unrest in Scotland in 1794 and 1820 were included in these figures as they were tried before commissions of Oyer and Terminer in Scotland.

21. For a study focused upon the North-East of England, see Gwenda Morgan and Peter Rushton, Rogues, Thieves and the Rule of Law; The Problem of Law Enforcement in North-East England, 1718-1800 (London: UCL Press, 1998). For a more recent analysis of the differences in the use of capital punishment for property offences in England's south-eastern metropolis and on the peripheries, see Peter King and Richard Ward, "Rethinking the Bloody Code in Eighteenth-Century Britain: Capital Punishment at the Centre and on the Periphery", Past and Present 228 (2015): 159-205.

22. NAS JC12 $/ 7 / 3$.

23. James Gray Kyd (ed.), Scottish Population Statistics Including Webster's Analysis of Population 1755 (Edinburgh: T and A Constable, 1952). 
24. Enumeration of the Inhabitants of Scotland, Taken from the Government Abstracts of 1801, 1811, 1821 (Glasgow: 1823).

25. R. A. Houston and I. D. Whyte, "Scottish Society in Perspective", in Scottish Society 1500-1800, ed. by R. A. Houston and I. D. Whyte, 1-36, 3, Cambridge: Cambridge University Press, 1989.

26. For a more thorough and long-term analysis, see Michael Flinn et al. (eds.), Scottish Population History from the Seventeenth Century to the 1930s (Cambridge: Cambridge University Press, 1977).

27. T. M. Devine, The Scottish Nation 1700-2000 (London: Penguin Press, 1999), 108.

28. T. M. Devine, The Transformation of Rural Scotland; Social Change and the Agrarian Economy, 1660-1815 (Edinburgh: Edinburgh University Press, 1994), 40.

29. David Turnock, The Historical Geography of Scotland since 1707 (Cambridge: Cambridge University Press, 1982), 153.

30. David G. Barrie and Susan Broomhall, "Public Men, Private Interests: The Origins, Structure and Practice of Police Courts in Scotland, c.1800-1833", Continuity and Change 27 (2012): 83-123, 96-97. See also W. W. J. Knox and A. McKinlay, "Crime, Protest and Policing in Nineteenth-Century Scotland", in A History of Everyday Life in Scotland, 1800 to 1900, ed. by Trevor Griffiths and Graeme Morton, 196-224, Edinburgh: Edinburgh University Press, 2010.

31. NAS JC13/14/93.

32. Enumeration of the Inbabitants of Scotland, 55.

33. Scots Magazine, Tuesday, 1 December 1818, 86.

34. Lord John MacLaurin, Arguments and Decisions in Remarkable Cases before the High Court of Justiciary and Other Supreme Courts in Scotland (Edinburgh: 1774), 705.

35. The attendance of the Sheriff Depute from each area was recorded in the circuit court minute books. A reading of the Northern Circuit records highlights the very infrequent attendance of successive Sheriff Deputes of Shetland and Orkney across this period. For examples of where the court made special note of this and instructed the clerk to write to them and to the High Court to report their non-attendance, see NAS JC11/13/11; $\mathrm{JC11} / 23 / 73$; JC11/49/44.

36. Following the insurrection in west-central Scotland in 1820, also referred to as the Radical War, 24 men were capitally convicted for treason which resulted in three executions and 21 remissions. Therefore, while Table 2.6 shows that $46.6 \%$ of capitally convicted offenders were executed in the 1820 s, if we remove those condemned for treason, the figure would be $52 \%$. 
37. W. W. J. Knox, with the assistance of L. Thomas, "Homicide in Eighteenth-Century Scotland: Numbers and Theories", The Scottish Historical Review 94 (2015): 48-73, 69-70. Note that Knox did not include infanticide cases in his figures and thus, particularly in the case of women, intimate killings would have accounted for a much higher proportion of the total homicide indictments.

38. For a study of illegitimacy and infanticide in England, see Mark Jackson, Newborn Child Murder: Women, Illegitimacy and the Courts in EighteenthCentury England (Manchester: Manchester University Press, 1996), 29-51.

39. NAS JC12/26/103.

40. NAS JC11 $/ 20 / 92$.

41. NAS JC8 $/ 2 / 109$.

42. NAS JC12/28/73.

43. King, Crime, Justice and Discretion, 280.

44. Hume, Commentaries, Vol. 1, 85.

45. NAS JC11/29/97.

46. Hume, Commentaries, Vol. 1, 103.

47. For a recent discussion of the end of transportation to America, see Barry Godfrey and Paul Lawrence, Crime and Justice Since 1750, Second Edition (Oxford: Routledge, 2015), 75.

48. Note that this figure includes all offenders executed for robbery as well as those convicted of robberies that had been charged along with the crime of stouthrief which was sometimes charged synonymously with robbery in the early nineteenth century and involved the use of violence within a dwelling place, and a couple of cases of robbery charged with the crime of hamesucken which was a common law crime wherein it was essential that breaking into a dwelling house was combined with personal violence. It appears that these crimes were additionally charged in the more serious robbery cases.

49. Henry Fielding, An Enquiry into the Causes of the Late Increase of Robbers, with Some Proposals for Remedying this Growing Evil (London: 1751), 1. See also, Hanging Not Punishment Enough for Murtherers, Highway Men and House-Breakers, Offered to the Consideration of the Two Houses of Parliament (London: 1701); John Fielding, A Plan for Preventing Robberies within Twenty Miles of London (London: 1755).

50. NAS JC7 $/ 25 / 425$.

51. King and Ward, "Rethinking the Bloody Code", 181.

52. Parliamentary Papers, Vol. XI (163) 1814-1815. A Return of Persons, Male and Female, Committed in the Years 1811, 1812, 1813 and 1814 to the Several Gaols in Scotland. 
53. Clive Emsley, Crime and Society in England 1750-1900 Fourth Edition (London: Routledge, 2013), 270.

54. NAS JC11/30/70.

55. The removal of many people from traditional land tenancies during the Highland Clearances to create space for sheep and cattle farms has received the attention of Scottish historians who have pointed towards not only the physical displacement of these people but also the further dislocation of traditional Highland society. Devine has highlighted at least 20 recorded major incidents of resistance to eviction between 1760 and 1855. See T. M. Devine, "Social Responses to Agrarian Improvement: The Highland and Lowland Clearances in Scotland", in Scottish Society 1500-1800, ed. by R. A. Houston and I. D. Whyte, 148-168, Cambridge: Cambridge University Press, 1989. However, it does not appear from the figures gathered for this research that the clearances led directly to an increase in the numbers of people capitally convicted for theft of sheep or cattle before the Justiciary courts.

56. Parliamentary Papers, Vol. XXXV (499) 1831-1832. Return of Number of Persons Brought for Trial for Capital Crimes before Justiciary Courts in Scotland, 1827-1831, 193-196.

57. Alison, Principles of the Criminal Law of Scotland, v.

58. Randall McGowen, "From Pillory to Gallows: The Punishment of Forgery in the Age of the Financial Revolution", Past and Present 165 (1999): 107-140, 107.

59. Randall McGowen, "Managing the Gallows: The Bank of England and the Death Penalty, 1797-1821", Law and History Review 25 (2007): 241-282, 243.

60. Emsley, Crime and Society, 271.

61. NAS JC7/45/15.

62. TNA HOl02/51/234.

63. Caledonian Mercury, Saturday, 4 June 1785, 3.

64. NAS JC7/40/357.

65. NAS JC13/43/41; Caledonian Mercury, Monday, 28 April 1817, p. 3.

66. NAS JC12/29/98.

67. NAS JC11/73/94.

68. Aberdeen Journal, Monday, 28 July 1800, 3.

69. NAS JC7/52/15.

70. Chester Courant, Tuesday, 19 December 1797, 2.

71. This fact was noted by Paul Riggs in his investigation of the prosecution's decision to restrict the charges in potentially capital cases for property offences, including forgery, by the 1830s. See Paul T. Riggs, "Prosecutors, Juries, Judges and Punishment in Early Nineteenth-Century Scotland", Journal of Scottish Historical Studies 32 (2012): 166-189. 
72. Radzinowicz, History of English Criminal Law, 594.

73. Jim Smyth and Alan McKinlay, "Whigs, Tories and Scottish Legal Reform c.1785-1832", Crime, History and Societies 15 (2011): 111-132, 128.

74. Crowther, "Scotland: A Country with No Criminal Record", 82-85.

Open Access This chapter is licensed under the terms of the Creative Commons Attribution 4.0 International License (http://creativecommons.org/licenses/ by $/ 4.0 /)$, which permits use, sharing, adaptation, distribution and reproduction in any medium or format, as long as you give appropriate credit to the original author(s) and the source, provide a link to the Creative Commons license and indicate if changes were made.

The images or other third party material in this chapter are included in the chapter's Creative Commons license, unless indicated otherwise in a credit line to the material. If material is not included in the chapter's Creative Commons license and your intended use is not permitted by statutory regulation or exceeds the permitted use, you will need to obtain permission directly from the copyright holder.

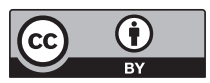

